\title{
Polk County v. Dodson: Liability Under Section 1983 for a Public Defender's Failure to Provide Adequate Counsel
}

Civil suits under 42 U.S.C. $\$ 1983,{ }^{1}$ which provides a cause of action against any person who, under color of state law, deprives another of a constitutional right, have been an important vehicle for the protection of constitutional rights. In Polk County v. Dodson, ${ }^{2}$ the United States Supreine Court construed the under color of state law requirement so as to limit the scope of section 1983. Polk County involved an indigent's section 1983 suit against a public defender who had withdrawn from the indigent's appeal from a robbery conviction. Justice Powell, writing for the inajority, held that a public defender does not act under color of state law when performing traditional functions as counsel. ${ }^{3}$ Justice Blackmun, the lone dissenter, argued that the Court's decision was contrary to its prior rulings on the ineaning of under color of state law and that the Court's decision would adversely affect the representation of indigent defendants. ${ }^{4}$

Part I of this Note presents the case. Part II analyzes the nueaning of the under color of state law requirement of section 1983, the central issue in Polk County, and argues that Justice Blackmun's analysis was essentially correct: both precedent and policy require the conclusion that public defenders act under color of state law. Part III considers the constitutional deprivation issue, an issue which the Court did not reach. Part III also argues that when a public defender lias withdrawn as counsel froin an indigent's appeal, in apparent coinpliance with the relevant procedural requirements, the burden should rest on the indigent to plead, with particularity, facts that annount to a deprivation of constitutional rights.

\section{42 U.S.C. \& 1983 (1976) provides:}

Every person who, under color of any statute, ordinance, regulation, custom, or usage, of any State or Territory, subjects, or causes to be subjected, any citizen of the United States or other person within the jurisdiction thereof to the deprivation of any rights, privileges, or immunities secured by the Constitution and laws, shall be liable to the party injured in an action at law, suit in equity, or other proper proceeding for redress.

2. 102 S. Ct. 445 (1981).

3. Id. at 453.

4. Id. at $445-59$ (Blackmun, J., dissenting). 


\section{I \\ The CASe}

Russell Richard Dodson had been convicted of robbery in Iowa District Court. Martha Shepard, an einployee of the Polk County Offender Advocates Office, ${ }^{5}$ was appointed to represent him on appeal. Shepard decided that Dodson's claims were frivolous and filed a inotion $^{6}$ with the Iowa Supreine Court to withdraw as counsel and to dismiss Dodson's appeal. Shepard accoinpanied her motion with an affidavit explaining her conclusion that Dodson's claims were frivolous and with a brief summarizing Dodson's legal arguments. The Iowa Supreme Court granted Shepard's motion.

In response, Dodson instituted an action under section 1983 in federal district court. His pro se complaint alleged that Shepard's actions, especially her inotion to withdraw, had "deprived him of his right to counsel, subjected him to cruel and unusual punishment, and arbitrarily denied him his state-created right to appeal in violation of the Fourteenth Amendment."7 The district court determined that Shepard had not acted under color of state law, and dismissed Dodson's suit for failure to state a claim cognizable under section $1983 .^{8}$

The Eighth Circuit Court of Appeals reversed, ${ }^{9}$ holding that public defenders act under color of state law even though their duties and obligations coincide with those of private attorneys. The court stated that this conclusion was necessary because the Iowa Offender Advocates were "employees of the County," which itself was "merely a creature of the State of Iowa." 10 One judge dissented, arguing that public defenders do not act under color of state law because their actions are not made possible solely because of their official status. ${ }^{11}$

The Supreme Court reversed the Eightl Circuit decision. In an opinion by Justice Powell, the Court held that public defenders do not

5. "The Offender Advocates Office is the independent creation of the Polk County Board of Supervisors. It or one of its lawyers is appointed by the court to represent indigent defendants ... . It is fully funded by Polk County." Dodson v. Polk County, 438 F. Supp. 347, 349 n.2 (S.D. Iowa 1979), aff'd in part, rev'd in part, 628 F.2d I104 (8th Cir. 1980), rev'd, 102 S. Ct. 445 (1981).

6. The motion was filed in conformance with rule 104 of the lowa Rules of Appellate Procedure. Rule 104 provides for dismissal of appeals found by the Iowa Suprene Court to be wholly frivolous. Id. at $348 \mathrm{n} .1$. It is similar to the procedure outlined in Anders v. California, 386 U.S. 738 (1967). See infra text accompanying notes 92-94.

7. Dodson v. Polk County, 438 F. Supp. at 348 . Dodson also asserted clains against Polk County, the Polk County Board of Supervisors, and the Polk County Offender Advocate. These claims, as well as Dodson's pendent state claims, were all dismissed by the United States Supreme Court. See Dodson v. Polk County, 102 S. Ct. at 454.

8. 438 F. Supp. at 350.

9. 628 F.2d 1104 (8th Cir. 1980), rev'd, 102 S. Ct. 449 (1981).

10. Id. at 1106.

11. Id. at 1109 (Overton, J., dissenting). 
act under color of state law while performing the traditional functions of counsel. ${ }^{12}$ The Court adopted the United States v. Classic ${ }^{13}$ definition of "under color of state law": "[m]isuse of power, possessed by virtue of state law and made possible only because the wrongdoer is clothed with the authority of state law, is action taken 'under color of' state law."14 The Court reasoned that Shepard's assignment entailed "functions and obligations in no way dependent on state authority." 15 The Court also noted that public defenders, unlike other state employees, are free from administrative direction because the state is constitutionally obligated to provide indigent defendants with independent advocates. ${ }^{16}$ Finally, the Court expressed concern that a holdmg that public defenders do act under color of state law would discourage states from providing post-conviction assistance and would impair imdigents' confidence im appointed counsel. ${ }^{17}$

Justice Blackmun, dissenting, noted that the Court's prior decisions had equated the under color of state law requirement of section 1983 and the state action requirement of the fourteenth amendinent. Finding that the activities of public defenders constitute state action, he thus concluded that such activities also constitute action imder color of state law. ${ }^{18}$ Moreover, Justice Blackmun noted that the Court had consistently presumed that full-time state officials act under color of state law. ${ }^{19}$ He predicted that the majority's analysis wonld either lead to lengthy hearings concerning the existence of section 1983 claims, ${ }^{20}$ or to the dismissal of all section 1983 claims agamst public defenders, even in instances of obvious state pressure and egregious deprivations of imdigents' civil rights. ${ }^{21}$

\section{II}

\section{The Under Color of State LAW Issue}

The Supreine Court has stated that any section 1983 action ini-

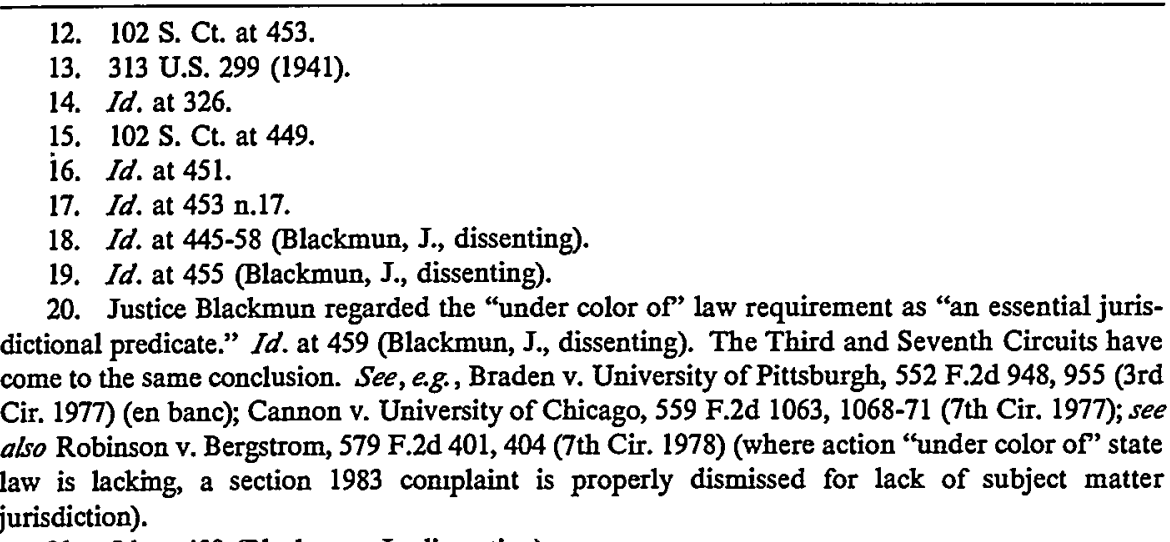

21. Id. at 459 (Blackmun, J., dissenting). 
tially "must focus on whether the two essential elements are present: (1) whether the conduct complained of was committed by a person acting under color of state law; and (2) whether the conduct deprived a person of rights, privileges or immunities secured by the Constitution or laws of the United States."22 Part III of this Note suggests the proper resolution of the constitutional deprivation issue when a public defender withdraws from an indigent's appeal. This Part, after first reviewing relevant prior cases, argues that the Court's conclusion that the action of public defenders does not constitute action under color of state law is contrary to precedent and public policy.

\section{A. Legal Background}

\section{The Traditional Formula}

The Supreme Court first construed the statutory language "under color of" state law when considering actions instituted under 18 U.S.C. $\S 242,{ }^{23}$ the criminal counterpart of section 1983. Subsequently, the Court has construed the statutory language "under color of" state law identically under sections 242 and $1983 .{ }^{24}$ Thus, the Court's early resolution of actions instituted under section 242 is considered next to set forth the traditional notion of action under color of state law.

In United States v. Classic, ${ }^{25}$ Louisiana election officials were accused of unlawful interference with state election procedures in violation of section 242. The defendants' acts were committed while performing their duties under state laws, primarily countmg ballots and certifying election results. The Supreme Court held that "[m]isuse of power, possessed by virtue of state law and made possible only because the wrongdoer is clothed with the authority of state law, is action taken 'under color of' state law."26

The Court applied and perhaps amplified the Classic definition in Screws $\nu$. United States, ${ }^{27}$ a case in which Georgia law enforcement officers were charged with violating section 242 for fatally beating a

22. Parratt v. Taylor, 451 U.S. 527, 535 (1981). Federal statutory rights which concern civil rights are protected under section 1983. See Chapman v. Houston Welfare Rights Org., 441 U.S. 600, 615-18 (1979); see also Lynch v. Household Finance Corp., 405 U.S. 538, 543-46 (1972). Such rights pertain, for example, to "nondiscrimination, voting, free speech and freedom of assembly . . . ." Dorak v. Shapp, 405 F. Supp. 863, 866 (M.D. Pa. 1975).

23. Section 242 provides criminal penalties for "[w] hoever, under color of any law, statute, ordinance, regulation, or custom, willfully subjects any inhabitant of any State, Territory, or District to the deprivation of any rights, privileges, or immunities secured by the Constitution or laws of the United States...."

24. See infra text accompanying note 45; see also McShane v. Moldovan, 172 F.2d 1016, 1020 (6th Cir. 1949).

25. 313 U.S. 299 (1941).

26. 313 U.S. at 326.

27. 325 U.S. 91 (1945). 
black citizen. The Court stated that action under color of law means action under "pretense" of law. "Thus acts of officers in the ambit of their personal pursuits are plainly excluded. Acts of officers who undertake to perform their official duties are included whether they hew to the line of authority or overstep it."28

For the next several decades, the district courts and courts of appeals applied consistently the principles articulated in Classic and Screws. ${ }^{29}$ Ultimately, in Monroe v. Pape, ${ }^{30}$ an action instituted under section 1983, the Supreme Court held that the meaning it had attributed to the statutory language of section 242 in Classic and Screws also defined "under color of" state law for purposes of section $1983 .{ }^{31}$

\section{The Previous Status of Public Defenders Under Section 1983}

Although the Supreme Court, prior to Polk County, had presumed that state employees acted under color of state law, ${ }^{32}$ the courts of appeals were in disagreeinent as to the status of public defenders under section 1983. In Espinoza v. Rogers, ${ }^{33}$ the Tenth Circuit Court of Appeals held that public defenders do not act under color of state law. The court reasoned that although the Public Defender's Office derived its existence from Colorado statutes, such statutes did not influence the professional judgment of public defenders. ${ }^{34}$ Similarly, the Third and Ninth Circuits, im Miller v. Barrillo ${ }^{35}$ and Brown v. Joseph, ${ }^{36}$ stated in dicta that public defenders do not act under color of state law. Both courts held that public defenders were entitled to absolute immunity ${ }^{37}$

28. Id. at 111 .

29. See, e.g., Geach v. Moynihan, 207 F.2d 714, 717 (7th Cir. 1953); Valle v. Stengel, 176 F.2d 697, 701 (3d Cir. 1949); McShane v. Moldovan, 172 F.2d 1016, 1019-20 (6th Cir. 1949); Westminster School Dist. v. Mendez, 161 F.2d 774, 778 (9th Cir. 1947); Burt v. City of New York, 156 F.2d 791, 792 (2d Cir. 1946); but see Deloach v. Rogers, 268 F.2d 928 (5th Cir. 1959).

30. 365 U.S. 167 (1961), overruled on other grounds, Monell v. Department of Social Services, 436 U.S. 658 (1978).

31. Id. at 187 .

32. In Flagg Bros. v. Brooks, 436 U.S. 149, 157 n.5 (1978) (citation omitted), the Court stated: "Of course, where the defendant is a pubhc official, the two elements of a $\$ 1983$ action merge. "The involvement of a state official . . - plainly provides the state action essential to show a direct violation of petitioner's Fourteenth Amendment . . rights . . '" Also, in Parratt v. Taylor, 451 U.S. at 535-36, the Court stated that certain prison officials had unquestionably acted under color of state law because they were "state employees in positions of considerable authority."

33. 470 F.2d 1174 (10th Cir. 1972).

34. Id. at 1174-75; see also Slavin v. Curry, 574 F.2d 1256, 1265 (5th Cir.) (holding that public defenders do not act under color of state law), modified mem., 583 F.2d 779 (5th Cir. 1978) (per curiam).

35. 549 F.2d 648 (9th Cir. 1977).

36. 463 F.2d 1046 (3d Cir. 1972), cert. denied, 412 U.S. 950 (1973).

37. Absolute immunity is an affirmative defense which protects an individual from liability under section 1983, even in suits alleging malicious and intentional malfeasance, as long as the individual commits the cliallenged action while performing official responsibilities. See generally 
from suit under section $1983 .{ }^{38}$

On the other hand, the Seventh Circuit held in Robinson v. Bergstrom $^{39}$ that a public defender does act under color of state law. The court recognized the identity between action under color of state law and state action under the fourteenth amendment. ${ }^{40}$ Accordingly, the court reasoned that "[i]n view of the [public defender] office's inextricable relation to the state, no proof that the [public defender's] challenged acts are related to the state is necessary." 41 The Robinson court furtlier held that public defenders have absolute immunity fron 1 hability under Section 1983.

\section{The Equivalence of the 'Under Color of State Law' and State Action Requirements}

Shortly after Monroe v. Pape, ${ }^{42}$ the Supreme Court decided United States $\nu$. Price, ${ }^{43}$ an action instituted under sections 241 and $242^{44}$ against state officials and others who had conspired to release and then kill imprisoned civil rights activists. The Court reiterated that under color of state law had the same meaning under section 242 as it did under section 1983. ${ }^{45}$ The Court also stated that in cases arising under section 1983, the under color of state law requirement had consistently been treated as having the same meaning as the state action requirement of the fourteenth annendment. ${ }^{46}$ The Court thus held that "[p]rivate persons, jointly engaged with state officials in the prohibited action, . . . [act] 'under color of' [state] law for purposes of the statute .... It is enough that . . . [one] is a willful participant in joint activity with the State or its agent."

The federal courts, ${ }^{48}$ with few exceptions, ${ }^{49}$ have adopted the Price

Nakles, Criminal Defense Lawyer: The Case for Absolute Immunity from Civil Liability, 81 Dick. L. Rev. 229 (1976).

38. Miller, 549 F.2d at $650 ;$ Brown, 463 F.2d at 1047-48.

39. 579 F.2d 401 (7th Cir. 1978).

40. Id. at 404 n.3.

41. Id. at 407-08.

42. See supra text accompanying notes $30-31$.

43. 383 U.S. 787 (1966).

44. 18 U.S.C. $\$ 241,242$ (1976). Section 241 prohibits private conspiracies that deprive individuals of constitutional rights. See supra note 23 for the text of section 242 .

45. 383 U.S. at 794 n.7.

46. $I d$.

47. Id. at 794. The Supreme Court followed the Price rationale in Adickes v. S.H. Kress \& Co., 398 U.S. 144 (1970), in which a customer of a privately operated restaurant instituted an action under section 1983 alleging deprivation of her equal protection rights. The Court not only recognized the Price Court's assimilation of state action and action under color of state law, but also reiterated that private persons, jointly engaged with the state or its agent in prohibited action, act under color of law for purposes of section 1983. Id. at 152.

48. See, e.g., Briley v. California, 564 F.2d 849 (9th Cir. 1977); Harley v. Oliver, 539 F.2d 1143 (8th Cir. 1976); Greco v. Orange Mcmorial Hosp. Corp., 513 F.2d 873 (5th Cir. 1975), cerf. 
approach and have thus equated action under color of state law and state action. Several of these courts ${ }^{50}$ have made reference to the theories of state action set forth in Burton v. Wilmington Parking Authority ${ }^{51}$ and Jackson v. Metropolitan Edison Co. ${ }^{52}$ Accordingly, prior to Polk County, several courts had suggested that the requirement of "state action" was essential to a section 1983 claim." 33

\section{B. The Necessity of Equating State Action and Action Under Color of State Law}

A failure to find that state action and action under color of state law are equivalent creates two insoluble problems: 1) it defeats section 1983's purpose as an enforcement mechanism for the fourteenth amendment; and 2) it creates confusion as to the meaning of under color of state law. Accordingly, if such problems are to be avoided, recognizing the equivalence of the two concepts is essential. ${ }^{54}$

First, failing to equate state action and action under color of state law contravenes the overriding purpose of section 1983 as an enforcement inechanism for the fourteenth amendment. This purpose is clear from the legislative history of section 1983 and has been affirmed by several courts. ${ }^{55}$ A failure to equate the two requirements creates the

denied, 423 U.S. 1000; Ouzts v. Maryland National Insurance Co., 505 F.2d 547 (9th Cir. 1974), cert. denied, 421 U.S. 949 (1975); Shirley v. State Nat'l Bank, 493 F.2d 739 (2d Cir.), cert. denied, 419 U.S. 1009 (1974); Williams v. Hamilton, 497 F. Supp. 641 (D.N.H. 1980).

49. See, e.g., Dieffenbach v. Attorney Gen., 604 F.2d 187 (2d Cir. 1979).

50. See, e.g., Robinson v. Bergstrom, 579 F.2d at 405-06; Hollenbaugh v. Carnegie Free Library, 545 F.2d 382, 383 (3d Cir. 1976), cert. denied, 439 U.S. 1052 (1978).

51. 365 U.S. 715 (1961). In Burton, a Negro citizen was refused service in a restaurant located in a publicly owned and operated parking building. The building had been constructed with public funds, for public purposes, and was owned and operated by a Delaware state agency, from which the private operator of the restaurant had leased its premises. The court reasoned that "[t]he State [had] insinuated itself into such a position of intcrdependence with [the restaurant] that [the state] must be recognized as a joint participant in the challenged activity." The Court thus concluded that the defendant's conduct could "not be considered to have been so "purely private' as to fall outside the scope of the Fourteenth Amendment." Id. at 725.

52. 419 U.S. 345 (1974). Jackson imvolved a section 1983 action against a privately owned and operated utihity company that had allegedly terminated the petitioner's service before giving her notice, a hearing, and an opportunity to pay any anounts found due. The Court held that the utikity's action was not attributable to the state for purposes of the fourtcenth amendment because Pennsylvania was not sufficiently connected with the private utilitys termination of the petitioner's service. Id. at 358 .

53. See, e.g., Robinson v. Bergstroin, 579 F.2d at 404; Braden v. University of Pittsburgh, 552 F.2d 948 (3d Cir. 1977); Cannon v. University of Chicago, 559 F.2d 1063 (7th Cir. 1976).

54. $102 \mathrm{~S}$. Ct. at 451 n.12. The Court nevertheless did not deem it necessary to consider the relationship between the two concepts in order to resolve Polk County. Id:

55. See, e.g., Ethridge v. Rhodes, 268 F. Supp. 83, 88 (S.D. Ohio 1967); United States v. Social Service Dept., 263 F. Supp. 971, 973-74 (E.D. Pa. 1967). Section 1983 was alternatively designated "An Act to enforce the Provisions of the Fourteenth Amendincnt to the Constitution of the United States, and for other Purposes." 17 Stat. 13 (1871). 
possibility that some behavior will constitute state action under the fourteenth amendment and yet not qualify as action under color of state law. Accordingly, to the extent behavior that constitutes state action deprives one of constitutional rights, and such behavior does not constitute action under color of state law, section 1983's purpose as an enforcement mechanism for the fourteenth amendment is contravened. ${ }^{56}$

Second, the Court's mability to differentiate between state action and action under color of state law demonstrates the necessity of equat$\mathrm{m} g$ the two concepts. Although the Court purported to adopt the Classic definition of under color of state law, the Court considered factors irrelevant to Classic. ${ }^{57}$ The Classic definition focuses on the source of the defendant's power. Yet, in holding that public defenders do not act under color of state law, the Court reasoned that public defenders perform a private function, and that public defenders are free from administrative control. ${ }^{58}$ Such considerations are irrelevant to the source of a public defender's power. They are more appropriately considered in determining whether behavior constitutes state action. ${ }^{59}$

The Court further confused the meaning of "under color of" state law by granting that it was possible for a state to so imfluence the behavior of a public defender that such behavior might constitute action under color of state law. ${ }^{60}$ However, the Court explamed neither the character nor the degree of state involvement sufficient to trigger such a finding. ${ }^{61}$ Accordingly, the Court's decision renders the meaning of "under color of" state law unclear. ${ }^{62}$

56. Id.

57. $102 \mathrm{~S}$. Ct. at 449-51.

58. Id. at 450-51.

59. See, e.g., Jackson v. Metropolitan Edison Co., 419 U.S. 345, $352-58$ (1974).

60. $102 \mathrm{~S}$. Ct. at 452 .

61. Id. at 451 n. 12 .

62. While this Note was in press, the Supreme Court explicitly held that action "under color of law" and "state action" are identical. Lugar v. Edmondson Oil Co., $102 \mathrm{~S}$. Ct. 2744, 2750-53 (1982); see also Rendell-Baker v. Kohn, 102 S. Ct. 2764, 2770 (1982); Blum v. Yarctsky, 102 S. Ct. 2777, 2788 n.20 (1982). In reaching this conclusion, the Lugar Court adopted reasoning substantially similar to that set forth in this Note. See supra text accompanying note 56. The Court reasoned that a failure to cquate the two rcquirements would be "wholly inconsistent" with section 1983's purpose as an enforcement mechanism for the fourteenth amendmcnt. Lugar v. Edmonson Oil Co., 102 S. Ct. 2744, 2752-53 (1982). The Court nevcrtheless maintained that Lugar "does not suggest a different outcome in Polk County." Id. at 2754 n.18.

Although both Lugar and Rendell-Baker explicitly stated that the two concepts are identical, the Court nevertheless implied that the under color of state law requirement of section 1983 might, under certain circumstances, be broader than the state action requirement of the fourteenth amendment. See Lugar v. Edmonson Oil Co., 102 S. Ct. 2744, 2753-54 n.18 (1982). 


\section{The Conduct of Public Defenders Constitutes State Action}

While the Court's "factual inquiry" led the majority to conclude that public defenders and the states are not joint participants in providing legal assistance to indigent defendants, a more thorough examination of the principles in the leading state action case of Burton $v$. Wilmington Parking Authority ${ }^{63}$ yields the contrary conclusion. Although the Court has never attempted the "impossible task" of reducing the state action concept to a single and infallible definition, ${ }^{64}$ factual similarities between Polk County and Burton render the principles articulated in Burton particularly appropriate to the resolution of whether the action of public defenders constitutes state action and, accordingly, action under color of state law. ${ }^{65}$

In Burton, the Court premised its finding of state action upon three particular aspects of the relationship between the defendant, a lessee of the state owned and operated Parking Authority, and the State of Delaware. First, the Court recognized that the commercially leased area was not surplus property, but was property which constituted "a physically and financially integral and, indeed, indispensable part of the state plan . .."66 Second, the Court emphasized the symbiotic nature of the relationship between the parties before the Court, i.e., the variety of mutual benefits which ran between the defendant and the state instrumentality. ${ }^{67}$ Third, the Court declared that the Authority, and thus the state, by failing to discharge fourteenth amendment obligations im negotiating the defendant's lease, had not only made itself a party to the challenged action, but had also "elected to place its power, property and prestige behind the admitted discrimination." 68

All of the Burton elements are present in Polk County and dictate a finding that the activities of public defenders constitute state action. First, the public defender system clearly "constitutes a physically and financially integral, and indeed indispensable part of the State's plan."69 The states have established and funded public defender offices to fulfill their constitutional obligation to provide counsel to indigents.

63. See supra note 51.

64. See, e.g., Reitman v. Mulkey, 387 U.S. 369, 378 (1967).

65. See infra text accompanying notes 69-73; see also Robinson v. Bergstrom, $579 \mathrm{~F} .2 \mathrm{~d}$ at 405-07. In Robinson, the court reasoned that whereas most cases dealing with the state action issue have involved claims against ostensibly private defendants, which had been statutorily delegated a public function, section 1983 cases against public defenders involve the converse of such claims, i.e., "that an employee of a clearly state-related instrumentality is not acting under color of state law because he exercises a private function." Id. at 406. Accordingly, the court applied the Burton principles and concluded that public defenders act under color of state law.

66. 365 U.S. at $723-24$.

67. Id. at $723-24$.

68. Id. at 725 .

69. 365 U.S. at $723-24$. 
Second, the relationship between the State and the public defender is symbiotic. The State provides the public defender with gainful employment and the public defender, in turn, discharges the State's responsibility to supply counsel to defendants. ${ }^{70}$

Finally, the extent of the state's involvement in the public defender system helps establish state action. The state prescribes the nuinber of public defenders and their levels of compensation; supervises their selection and appointinent; and determines the attributes of indigency. ${ }^{71}$ Through these activities, the State exercises substantial influence over the size of a public defender's caseload. Hence, the State controls the amount of time a public defender can devote to any particular case, ${ }^{72}$ and thus directly affects the quality of an indigent's representation. Therefore, the conduct of public defenders constitutes state action because the State lias made itself a party to the representation and has elected to place its power, property, and prestige behind the public defender's action. ${ }^{73}$

\section{Public Policy Supports the Conclusion that Public Defenders Act Under Color of State Law}

The Court did not accurately assess the impact of its finding that public defenders do not act under "color of law" for purposes of section 1983. A thorough examination of both the Court's reasoning and the impact of its finding upon the competing interests will show that pubhic defenders should be ainenable to suit under section 1983.

The Court set forth three reasons in support of its conclusion that

70. Id. at $723-25$.

71. See, eg., IOWA CODE ANN. $\S \S 336$ A.1-.5 (West 1977).

72. See, e.g., Robinson v. Bergstrom, 579 F.2d at 402 (public defender delayed five years in filing an appellate brief, due to "an error in his judgment regarding lis caseload," which approaclied 600-900 cases per year).

73. The Court's recent decisions in Rendell-Baker v. Kolin, 102 S. Ct. 2764 (1982), and Blum v. Yaretsky, 102 S. Ct. 2777 (1982), do not dictate a contrary conclusion. Although the Court considered Burton principles in both cases and concluded that the defendants' conduct did not constitute state action, Rendell-Baker and Blum are distinguishable froin Polk County.

In Rendell-Baker, forner teacliers brought suit under section 1983 against a private school alleging violations of their constitutional rights in connection with their discharge. Sinilarly, in Blum, actions were brought concerning a private nursing lome's decisions to reclassify its patients, allegedly in violation of their due process rights. Rendell-Baker and Blum differ froin Polk County in two inaterial respects: (1) the cliallenged conduct in Rendell-Baker and Blum, unlike the challenged conduct in Polk County, was not committed by state einployees; and (2) the states in Rendell-Baker and Blum, unlike the state in Polk County, were not constitutionally obligated to provide the "challenged services" to the aggrieved parties. Therefore, whereas in Polk County, the state provided the public defender witl gainful employinent and the public defender, in turn, discharged the state's responsibility to provide counsel to mdigents, no such symbiotic relationship existed in either Rendell-Baker or Blum. Accordingly, although the Court failed to find state action in Rendell-Baker and Blum, such decisions do not logically suggest an absence of state action in Polk County. 
public defenders do not act under color of state law: (1) public defenders are independent advocates; (2) public defender liability under section 1983 would decrease indigents' confidence in appointed counsel; and (3) public defender liability under section 1983 would create a disincentive for states to provide counsel to indigents. The Court correctly noted that public defender liability might create sucl a disincentive. The balance of the Court's reasoning, lowever, overwhelmingly supports the conclusion that public defenders act under color of state law.

First, the Court reasoned that public defenders do not act under color of state law because they are independent advocates. The Court noted that unlike other state enployees, public defenders are ethically and constitutionally required to be free from administrative control. ${ }^{74}$ It was upon this basis that the Court atteinpted to distinguish public defenders from physicians einployed in state institutions who had previously been held to act under color of state law. ${ }^{75}$

Assuming that public defenders nay be distinguished from physicians on the basis that public defenders are freer from administrative control, this distinction suggests that a section 1983 remedy is appropriate. To the extent that public defenders are independent advocates, they perform their duties without rules or regulations to restrict their discretion or to facilitate their compliance with the Constitution. Without such rules or regulations, constitutional deprivations may be more likely. Moreover, when an indigent is deprived of effective assistance of counsel, the deprivation often precludes alternative relief. ${ }^{76}$ There- $^{-}$ fore, because public defenders exercise substantial discretion while discharging the state's constitutional obligations, the section 1983 remedy is appropriate. Otherwise, a deprivation of effective assistance might elude judicial review. ${ }^{77}$

74. See supra text accoinpanying note 16 .

75. See Estelle v. Gamble, 429 U.S. 97 (1976); O'Connor v. Donaldson, 422 U.S. 563 (1975). The Polk County dissent argued against such a distinction on the ground that an institutional physician has a constitutional duty to provide adequate inedical care, see Estelle v. Gamble, 429 U.S. at 106, which may conflict with institutional policies and practices. The dissent viewed the public defender situation as analogous. Polk County v. Dodson, $102 \mathrm{~S}$. Ct. at 456 (Blackmun, J., dissenting).

76. Waltz, Inadequacy of Trial Defense Representation as a Ground for Post-Conviction Relief in Criminal Cases, 59 Nw. U.L. REv. 289, 290 n.7 (1964) (noting the infrequency of motions for new trials, due to defense lawyers' reluctance to brand their own conduct as "grossly inadequate"); see also Robinson v. Bergstrom, 579 F.2d 401 (7th Cir. 1978) (public defender's delay in filing appellate brief barred indigent's filing labeas corpus petition).

77. A finding of state action would not unduly interfere with a public defender's autonomy. First, section 1983 is limited to deprivations of constitutional magnitude. Second, an indigent's general or conclusory allegations of ineffective assistance are not sufficient to state a cause of action under section 1983. See Waltz, supra note 76, at 295; see also Douglas v. California, 372 U.S. 353, 358 (1962) (Clark, J., dissenting). Third, some federal courts have extended public defenders quasi-judicial immunity, and have thus provided them with significant protection from the unmeritorious claims of indigents under section 1983. See supra text accompanying note 38. 
Second, the Court expressed concern that if it found that public defenders act under color of state law, the resulting amenability of public defenders to section 1983 liability would impair the confidence of indigents in public defenders. ${ }^{78}$ The Court failed to explain the basis for its concern. It is unlikely that the Court's decision, which eliminates the indigent's section 1983 reinedy against public defenders, will preserve or inspire the indigent's confidence. Rather, the availability of a section 1983 reinedy would likely enhance an indigent's confidence in public defenders; a public defender facing the prospect of personal liability under section 1983 would have a greater incentive to provide effective assistance than is otherwise present. ${ }^{79}$ Thus, because public defenders will likely provide more effective counsel if subjected to section 1983 liability, a finding that public defenders act under color of state law would tend to increase indigents' confidence in public defenders.

Third, the Court expressed concern that a finding that public defenders act under color of state law might create a disincentive for a state to provide indigents with counsel. ${ }^{80}$ Apparently, the Court reasoned that public defender liability under section 1983 would disrupt the efficiency of public defender systems and that states would therefore hesitate to provide legal assistance beyond the constitutional minimum.

Assuming the existence of such a dismcentive, the Court's reasoning is of limited significance. This disincentive operates solely to the extent that a state provides assistance beyond that which is constitutionally required. Although in Polk County, the state did provide inore legal assistance than constitutionally guaranteed, this disincentive does not dictate a finding that public defenders do not act under color of

Therefore, a failure to find state action would generally confer unnecessary protection upon public defenders.

78. 102 S. Ct. at 453.

79. Alternative incentives for effective assistance of counsel are inadequate. First, an indigent who has not received effective assistance might obtain habeas corpus rehief. Such relief, however, is not as effective as section 1983 because it does not provide public defenders with the threat of personal hability. Second, although criminal proceedings against public defenders under 18 U.S.C. $\$ 242$ might create incentives for providing effective assistance, such proceedings have only been successful in cases involving willful and outrageous deprivations of civil rights. See, e.g., United States v. Senak, 477 F.2d 304, 308 (7th Cir. 1973). In contrast, all constitutional deprivations are cognizable under section 1983. Third, the threat of personal liability under state unalpractice laws might arguably provide an incentive for effective assistance. This incentive, however, would be eliminated if a state court extended public defenders absolute immunity from state inalpractice liability. Although federal courts might similarly extend public defenders absolute immunity froin liability under section 1983, this Note argues that this would be improper. See infra note 106. Liability under section 1983, unlike liability under state malpractice laws, would assure an incentive for providing effective assistance which would be uniform among the states.

80. See $102 \mathrm{~S}$. Ct. at 453 n. 17 . 
state law. The prospect of public defender liability under section 1983 would strengthen the incentive for effective assistance and increase the confidence of indigents in public defenders. These two factors arguably outweigh any possible disincentive and support the conclusion that public defenders act under color of state law.

III

The Constitutional Deprivation Issue

The Court did not reach the issue of whether Dodson had satisfied the second element of section 1983, that is, whether lie had been deprived of a constitutional right. An examination of the Court's prior loldings suggests that where a public defender has withdrawn froin an indigent's appeal, in apparent compliance with the procedures set forth in Anders $v$. California, ${ }^{81}$ the burden rests on the indigent to plead with particularity facts that constitute a deprivation of a constitutional riglit. Therefore, altliough Dodson's attorney acted under color of law, Dodson's section 1983 action should lave been remanded to determine whether Dodson had pleaded ${ }^{82}$ with particularity facts deinonstrating that his attorney had not met the Anders requirements. ${ }^{83}$

\section{A. Legal Background}

\section{An Indigent's Right to Appellate Counsel}

In Griffin v. Illinois, ${ }^{84}$ the Supreme Court declared that where a state grants appellate review, it inust do so in a manner that does not discriminate agaimst convicted defendants on account of their poverty. The Court held that the State of Illinois' failure to furnish certified transcripts to imdigent appellants constituted an invidious discrimination which violated both the due process and equal protection clauses. ${ }^{85}$

81. 386 U.S. 738 (1967).

82. Dodson alleged that Shephard's activities, especially her motion to withdraw from his appeal, had deprived him of his right to counsel, had subjected him to cruel and unusual purishment, and had arbitrarily denied him his state-created right to appeal in violation of the fourteenth amendment. $102 \mathrm{~S}$. Ct. at 448. Dodson's first two allegations are frivolous. First, although in Gideon v. Wainwright, 372 U.S. 335 (1963), the sixth amendment's requirement that an indigent "shall enjoy the right . . . to have the Assistance of Counsel for his defense," was held to be obhigatory on the states through the fourteenth amendment, the Gideon Court did not hold that an indigent had a sixth amendment right to counsel on appeal from a state conviction. State appellate procedures "stand on an entirely different constitutional footing" than analogous federal procedures; state appellate review is not constitutionally required. Second, Dodson's allegation of cruel and unusual punishment depends upon his establishment of an alternative basis of constitutional infirmity. Therefore, Dodson's "right to counsel" need only be examined within the context of the equal protection clause of the fourteenth amendment. See infra text accompanying notes 88-91, 97.

83. See infra text accompanying notes $92-94$.

84. 351 U.S. 12 (1956).

85. Id. at $17-20$. 
Subsequently, in Douglas v. California ${ }^{86}$ the Supreme Court invalidated a state procedure pursuant to which a state appellate court was to examine an indigent's trial record and appoint or deny counsel accordingly. The Court reasoned that the state's denial of appellate counsel, pursuant to the California procedure, constituted "a discrimination at least as invidious as that condemned in Griffin v. Illinois, [and that] there can be no equal justice where-the kind of appeal a man enjoys 'depends on the amount of inoney he has.' "87

The Court again considered the extent of an indigent's right to appellate counsel in Ross v. Moffit ${ }^{88}$ The Court noted that the preeise rationale for the Griffin and Douglas decisions had never been explicitly stated, though "some support [was] derived from the Equal Protection Clause, and some from the Due Process Clause of [the Fourteenth] Amendment." 89 However, the Court concluded that the deternination of the constitutionality of state appellate procedures is "inore profitably considered under an equal protection analysis." "90 The Court upheld the relevant state and federal procedures for the appointment of counsel in discretionary appeals and stated that "[t] he duty of the State under our cases is not to duplicate the legal arsenal that may be privately retained by a criminal defendant . . ., but only to assure the indigent defendant an adequate opportunity to present his claims fairly in the context of the State's appellate process." 91

Thus, Ross confirmed that an indigent does not have a constitutional right to the best counsel that inay be privately obtained. Although a criminal defendant who can afford counsel nay pursue frivolous appeals, the Constitution affords an indigent no such right.

\section{The Procedures for Withdrawal from an Indigent's Appeal}

In Anders $v$. California, ${ }^{92}$ the Court considered the extent of a court appointed attorney's duty to prosecute an indigent's appeal from a state criminal conviction after such attorney had determined the appeal was frivolous. The Court held that counsel, after a conscientious determi-

86. 372 U.S. 353 (1963).

87. Id. at 355. Justice Harlan dissented and argued that the procedure provided "[an] indigent appellant [with] the benefit of expert and conscientious legal appraisal of the merits of his case on the basis of the trial record, and whether or not he is assigned counsel, [an indigent] is guaranteed full consideration of his appeal." Id. at 365. Justice Clark, in a separate dissent, would have sustained the California procedure on the alternative ground that it did not place the determination as to appoimtment of counsel in the unreviewable discretion of the public defender, but rather in the discretion of the appellate court itself. Id. at 359-60.

88. 417 U.S. 600 (1974).

89. Id. at $608-09$.

90. Id. at 611 .

91. Id. at 616 .

92. 386 U.S. 738 (1967). 
nation that an indigent's appeal is frivolous, should advise the court and request permission to withdraw..$^{93}$ To comply with Anders, the court appointed attorney must also file a brief referring to anything in the record that might arguably support the appeal. This brief inust also be furnished to the indigent so that he may present supporting arguments to the court.

After the brief is filed, Anders requires a court to determine whether the appeal is frivolous. If the court makes such a finding, it is required to grant counsel's request to withdraw and to dismiss the appeal, unless state law requires a decision on the merits. If the court finds that the indigent has stated a case that is not frivolous, however, it inust provide the indigent with counsel for the appeal. ${ }^{94}$ The Anders Court clearly imphed that the procedure it set forth would comport with the constitutional requirements of "substantial equality and fair process" 95 because it would assure indigents, "as nearly as is practicable,"96 the same rights and opportunities on appeal as those enjoyed by persons who can afford to retain counsel.

\section{B. The Resolution of the Constitutional Deprivation Issue}

Because of the Court's approach in Ross v. Moffitt, ${ }^{97}$ the question whether Dodson had been deprived of his constitutional rights narrows to whether the dismissal of Dodson's appeal, pursuant to rule 104 of the Iowa Rules of Appellate Procedure, violated Dodson's rights under the equal protection clause of the fourteenth amendment. ${ }^{98}$ The procedure prescribed in rule 104 contains all of the procedural safeguards outlined by the Supreine Court in Anders $v$. California. ${ }^{99}$ The rule requires: 1) that counsel accompany a motion to withdraw with a brief which sets forth an indigent's supporting legal argunients; 2) that an imdigent be provided notice and an opportunity to raise argunients on his or her behalf; 3 ) that the court review the record and decide whether an appeal shall proceed; and 4) that the court reappoint counsel if it finds merit in the indigent's appeal. ${ }^{100}$

Shepard's motion to withdraw and the Iowa Suprene Court's dismissal of Dodson's appeal were both executed in apparent compliance

\footnotetext{
93. Id. at 744.

94. Id.

95. Id.

96. Id. at 745 .

97. See supra text accompanying notes $88-89$.

98. See supra note 90.

99. See supra text accompanying notes 93-94. .

100. The Court noted that rule 104 was "very similar"s to the procedure outlined in Anders, and that "[i]t is the obligation of any lawyer-whether privately retained or publicly appointednot to clog the courts with frivolous motions or appeals." $102 \mathrm{~S}$. Ct. at 448 n.2, 452.
} 
with rule 104. Anders clearly suggests that comphance with its procedures satisfies the constitutional requirements of "substantial equality and fair process."101 Nevertheless, the Court failed to recognize the resultant improbability that Dodson had been deprived of his equal protection rights. ${ }^{102} \mathrm{Had}$ it done so, it might lave held that where a public defender withdraws as counsel from an indigent's appeal, in apparent compliance with the procedural requirements set forth in $\mathrm{An}$ ders,${ }^{103}$ the burden rests on the indigent to plead with particularity facts which constitute a deprivation of constitutional rights. ${ }^{104}$

Such a holding would reinforce the rule that an indigent's general or conclusory allegations of imeffective assistance are not sufficient to state a cause of action under section 1983. ${ }^{105}$ Moreover, had the Court required sucl pleadimg witlı particularity, federal trial courts could dismiss, at the pleading stage, unmeritorious section 1983 claims alleging that a public defender's witlidrawal constituted a constitutional deprivation. Therefore, the Court could lave lessened the threat of public defender hability under section 1983 without impeding an indigent's access to section 1983 for the redress of colorable deprivations of constitutional rights. ${ }^{106}$

\section{CONCLUSION}

In Polk County, the United States Supreme Court improperly concluded that public defenders, when performing the traditional functions of counsel, do not act under color of state law. The Court failed to provide convincing reasons why public defenders, unlike other state employees, sliould not be amenable to suit under section 1983 for their failure to adhere to the provisions of the Constitution during the performance of their official duties. The Court imcorrectly adopted the

101. See supra text accompanying note 95 .

102. See Douglas v. California, 372 U.S. 353, 358 (1962) (Clark, J., dissenting) ("We all know that the overwhelming percentage of in forma pauperis appeals are frivolous. Statistics of this Court show that over $96 \%$ of the petitions filed here are of this variety."); see also Waltz, supra note 76, at 296.

103. See supra text accompanying notes $94,100$.

104. Accordingly, the Court should have remanded Polk County to the trial court, where, pursuant to the preceding rule, the burden would rest on Dodson to prove, with particularity, facts which allege that Shepard's withdrawal from Dodson's appeal deviated from the Anders formalities and thus deprived Dodson of his constitutional rights.

105. See supra note 77.

106. To the extent that public defenders require additional protection from potential section 1983 liability, the federal courts should grant them qualified, i.e., good faith, immunity from suits under section 1983. See, e.g., Polk County v. Dodson, 102 S. Ct. at 460 (Blackmun, J., dissenting); Comment, Liability of Public Defenders Under Section 1983: Robinson v. Bergstrom, 92 HARV. L. REv. 943, 950-51 (1979) (supporting qualified immunity for public defenders). But see Black v. Bayer, 672 F.2d 309 (3d Cir. 1982) (holding public defenders have absolute immunity from section 1983 liability). 
United States v. Classic definition of under color of state law and incorrectly intimated that differences exist between the relevant statutory language of section 1983 and the state action principle of the fourteenth amendment.

The state action principle is an essential tool for the proper determination of federal jurisdiction over section 1983 claims. Its flexibility permits a court not only to detect significant state involvement in allegedly private behavior, but also to assess the impact of section 1983 rehef on the parties before the court. An application of the state action principle to Polk County reveals the significant connection between state entanglenent in the provision of public defender services and the quality of the legal services which indigents actually receive. It further reveals that an indigent's interest in access to section 1983 relief significantly outweighs a public defender's need to be free fron section 1983 complamts which allege the deprivation of an indigent's constitutional rights. Accordingly, the Court should have held that public defenders do act under color of state law.

The Court did not reach the issue of whether Dodson had been deprived of his constitutional rights. The Court's prior holdings suggest that where a public defender withdraws frown an indigent's appeal, pursuant to Anders v. California, the burden rests on the indigent to plead with particularity facts that constitute a deprivation of constitutional rights. Thus, where an indigent fails to plead facts which demonstrate that a public defender has deviated froin Anders, the indigent's section 1983 claim shonld be dismissed.

Kenneth Scott Schlesinger*

* A.B. 1980, University of Michigan; third year student, Boalt Hall School of Law, University of California, Berkeley. 